Arq. Bras. Med. Vet. Zootec., v.66, n.2, p.347-354, 2014

\title{
A Lactobacillus rhamnosus strain induces protection in different sites after Salmonella enterica subsp. enterica serovar Typhimurium challenge in gnotobiotic and conventional mice
}

\author{
[Uma cepa de Lactobacillus rhamnosus induz proteção em diferentes sítios em \\ camundongos gnotobióticos e convencionais após desafio com Salmonella enterica \\ subsp. enterica sorovar Typhimurium]
}

\author{
A.H. Mendonça ${ }^{1}$, M.M.O.P. Cerqueira ${ }^{1 *}$, J.R. Nicoli ${ }^{2}$, S.M.M. Sousa ${ }^{1}$, R.M.D. Nardi ${ }^{2}$, \\ F.N. Souza ${ }^{1}$, L. M. Fonseca ${ }^{1}$, M.O. Leite ${ }^{1}$, R.M.E. Arantes ${ }^{2}$ \\ ${ }^{1}$ Escola de Veterinária - Universidade Federal de Minas Gerais - Belo Horizonte, MG \\ ${ }^{2}$ Instituto de Ciências Biológicas - Universidade Federal de Minas Gerais- Belo Horizonte, MG
}

\begin{abstract}
The ability of a Lactobacillus rhamnosus strain isolated from a healthy breast-fed human newborn to reduce the pathological consequences for the host due to an experimental oral infection with Salmonella enterica subsp. enterica serov. Typhimurium in vivo was determined using gnotobiotic and conventional mice. Conventional mice received $0.1 \mathrm{~mL}$ probiotic milk ( $8.0 \log$ colony-forming unit) daily for 10 days before the oral pathogenic challenge (5.0 log colony-forming unit). Then probiotic treatment was continued until the end of the experiment. Probiotic treatment in germ-free mice consisted of a single dose of the probiotic milk at the beginning of the experiment and a challenge with $S$. Typhimurium 10 days later (3.0 log colony-forming unit). A protective effect was observed in both gnotobiotic and conventional animals in terms of histopathologic and morphometric data, but in different anatomical sites. This protection was observed in liver and intestines, respectively, for gnotobiotic and conventional mice. However, $S$. Typhimurium populations were similar in the feces of both treated and control gnotobiotic mice. We conclude that a protective effect of $L$. rhamnosus against experimental $S$. Typhimurium was observed. This protection was not due to the reduction of the population of pathogenic bacteria in the intestine.
\end{abstract}

Keywords: intestinal infection, lactobacilli, probiotics, Salmonella

\section{RESUMO}

A habilidade de uma cepa de Lactobacillus rhamnosus isolada de um recém-nascido saudável de reduzir as consequências patológicas para o hospedeiro após infecção experimental por Salmonella enterica subsp. enterica sorov. Typhimurium foi avaliada em camundongos gnotobióticos e convencionais. Os camundongos convencionais receberam $0,1 \mathrm{~mL}$ de leite probiótico por dia $(0,8$ log unidade formadora de colônia), 10 dias antes do desafio oral com S. Typhimurium (5,0 log unidade formadora de colônia), $e$ continuaram recebendo probiótico até o término do experimento. $O$ tratamento com probiótico nos camundongos gnotobióticos consistiu em uma única dose de leite probiótico no início do experimento e desafio oral após 10 dias (3,0 log unidade formadora de colônia). Em termos histopatológicos e morfométricos, a proteção foi observada no figado e nos intestinos nos animais gnotobióticos e convencionais, respectivamente. No entanto, a população de S. Typhimurium foi similar em ambos os grupos tratado e controle de animais gnotobióticos. Desta forma, conclui-se que a proteção conferida pela cepa de L. rhamnosus contra o desafio experimental S. Typhimurium foi observada em diferentes sítios anatômicos nos animais convencionais e gnotobióticos e que essa proteção não foi devido à redução da população de S. Typhimurium nos intestinos.

Palavras-chave: infecção intestinal, lactobacilos, probióticos, Salmonella

Recebido em 26 de março de 2012

Aceito em 12 de setembro de 2013

* Autor para correspondência (corresponding author)

E-mail: monicamopc@ufmg.br 


\section{INTRODUCTION}

Salmonella enterica subsp. enterica serov. Typhimurium are important facultative intracellular pathogens that are implicated in human foodborne illnesses and often enter the human food supply via contamination of poultry, pork, beef and dairy products (Burkholder and Bhunia, 2009). In humans, Salmonella spp. is responsible for over one billion infections annually, with consequences ranging from selflimiting gastroenteritis to typhoid fever. A wide range of antimicrobials are used to treat salmonellosis, however, genetic mutations and selective pressure have induced Salmonella spp. to become resistant or multi-resistant to these antimicrobials (Martins et al., 2010).

The widespread prescription of antimicrobials not only led to an increase in the antimicrobialresistant bacterial pathogen strains, but is also often associated with the disruption of the protective microbiota, leading to predisposition to infections. For these reasons, the control of infections through a non-antimicrobial approach is urgently needed (Forestier et al., 2001; Shu and Gill, 2002). It has long been acknowledged that fermented milk-based diets, such as yogurt, can confer enhanced resistance against infection with enteric pathogens to individuals. This enhanced resistance is thought to be effected by the presence of probiotics, therefore certain probiotic strains may be a useful dietary supplement to combat enteric pathogens in humans and animals (Shu and Gill, 2002; Robinson et al., 2010).

Probiotics are food or pharmaceutical preparations containing "live non-pathogenic microorganisms which, when administrated in adequate amounts, confers a health benefit to the host" (FAO/WHO, 2002). The potential mechanisms by which probiotic agents might exert their protective or therapeutic effect against infections include: antagonism by the production of substances which inhibit or kill the pathogen; competition with the pathogen for adhesion sites or nutritional sources; immunomodulation of the host; and inhibition of the production or action of bacterial toxin (Robinson et al., 2010). The likely contribution of each of these mechanisms is difficult to determine in the presence of a broad and complex gastrointestinal microbiota. The use of the gnotobiotic animal model with a simplified intestinal microbial status allows the in vivo observation of interactions between a probiotic, a pathogenic bacterium and the host (Silva et al., 1999).

The Lactobacillus rhamnosus strain used in the present study was isolated at the Federal University of Minas Gerais from a breast-fed healthy newborn with the objective of isolating a new probiotic for human use. This strain showed antagonistic properties against enteropathogenic bacteria by both in vitro and ex vivo (inhibitory zone around feces from gnotobiotic mice monoassociated with L. rhamnosus) assays, in our previous experiments.

Thus, the aim of the present study was to investigate if this $L$. rhamnosus strain can antagonize Salmonella enterica subsp. enterica serov. Typhimurium, in vivo, and consequently reduce the pathological consequences for the host using gnotobiotic and conventional mice.

\section{MATERIAL AND METHODS}

Germ-free 21-day-old NIH mice (Taconic, Germantown, USA) were used in this work. The animals were housed in flexible plastic isolators (Standard Safety Equipment Company, McHenry, USA) and handled according to the established procedures (Pleasants, 1974). Experiments with gnotobiotic mice were carried out in micro-isolators (UNO Roestvaststaal B.V., Zevenaar, The Netherlands). Conventional NIH mice were derived from the germ-free colony and used onlyafter at least two generations following the conventionalization. Water and commercial autoclavable diet (Nuvital, Curitiba, Brazil) were sterilized by steam and administered ad libitum to all the animals. Conventional mice were maintained in an open animal house, and controlled lighting (12 h light, $12 \mathrm{~h}$ dark) was used for all the animals. All experimental procedures were carried out according to the standards set forth in the "Guide for the Care and Use of Laboratory Animals" from the National Research Council (National..., 1996).

Each gnotobiotic and conventional group consisted of 10 and 30 mice, respectively. Population levels of the pathogenic bacteria and L. rhamnosus in the feces of gnotobiotic mice and cumulative mortality for all the animals were recorded during the challenge experiments. At 
the end of the experiments, all remaining mice were sacrificed by cervical dislocation.

The Lactobacillus rhamnosus strain used in the present study was isolated from a healthy breastfed human newborn at the Federal University of Minas Gerais, Belo Horizonte, Brazil, and maintained at $-86^{\circ} \mathrm{C}$ in de Man, Rogosa and Sharp (MRS) broth (Difco, Sparks, USA) supplemented with $15 \%$ glycerol. Salmonella enterica subsp. enterica serov. Typhimurium was obtained from Fundação Ezequiel Dias (FUNED, Belo Horizonte, Brazil) and maintained at $-70^{\circ} \mathrm{C}$ in brain heart infusion (BHI) broth (Difco) containing 20\% glycerol.

Fermented milk was prepared from $10 \%$ reconstituted skim milk inoculated with a $2 \%$ culture of L. rhamnosus in MRS broth (Difco) and incubated at $37^{\circ} \mathrm{C}$ during 20 hours. A single dose of fermented milk $(0.1 \mathrm{~mL})$ containing about $8.0 \mathrm{log}$ of colony-forming units (CFU) of $L$. rhamnosus was administered to germ-free mice by intragastric intubation 10 days before the experimental challenge with pathogenic bacteria. The same dose was administered daily to conventional mice, 10 days before the challenge and during the remaining experimental period. The control conventional and gnotobiotic groups were treated with $0.9 \%$ saline according to the same schedule as the corresponding experimental groups.

S. Typhimurium was grown in BHI broth (Difco) at $37^{\circ} \mathrm{C}$ during $24-48$ hours under aerobic conditions. Mice were inoculated through the intragastric route with $0.1 \mathrm{~mL}$ of the bacterial suspension containing 3.0 or $5.0 \log \mathrm{CFU}$ for gnotobiotic or conventional mice, respectively.

Freshly collected feces from gnotobiotic mice were immediately introduced in an anaerobic chamber (Forma Scientific, Marietta, USA, containing an atmosphere of $85 \% \quad \mathrm{~N}_{2}, 10 \%$ $\mathrm{H}_{2}$ and $5 \% \quad \mathrm{CO}_{2}$ ), diluted 100 -fold in saline and vortexed. Serial 10 -fold dilutions were performed and $0.1 \mathrm{~mL}$ plated onto McConkey agar (Difco) for $S$. Typhimurium and MRS agar (Merck, Darmstadt, Germany) for L. rhamnosus and incubated at $37^{\circ} \mathrm{C}$ for $24-48$ hours for bacterial counts under aerobic or anaerobic conditions, respectively.

Tissue samples from different regions of the liver and intestines of mice sacrificed at the end of the experiments were fixed in buffered $4 \%$ formaldehyde and processed for paraffin embedding. The histopathological sections $(3-5 \mu \mathrm{m})$ were stained with hematoxylin-eosin. The slides were coded and examined by a single pathologist, who was unaware of the experimental conditions of each group. For morphometric examination of the liver, the images were obtained by a JVC TK-1270/RGB microcamera and the KS 300 Software built in a Kontron Elektronick/Carl Zeiss image analyzer (Oberkohen, Germany). The inflammatory foci were considered as a damage index for hepatic tissue. Inflammatory focus is defined as the accumulation of inflammatory cells in number higher than 10 cells, accompanied by necrotic alterations of the associated parenchyma. The unit of inflammatory foci measured in all animals is the sum of ten $10 x$ - objective fields.

The statistical significance of the results was evaluated by the Student's $t$ test, Fisher exact test or Mann-Whitney Rank test depending on the data. The level of significance was set at $P \leq 0.05$. Statistical analyses were performed using the Sigma Stat program (Jandel Scientific Software, version 1.0, San Rafael, CA, USA).

\section{RESULTS}

A better preservation of the hepatic tissue was observed in the treated group (Fig. 1b) when compared to control animals (Fig. 1a) from gnotobiotic mices after the pathogenic challenge. This fact was confirmed by a higher $(P<0.05)$ number of inflammatory foci in the gnotobiotic control group when compared to its treated counterpart (Fig. 2). In the intestines of gnotobiotic animals, lesions were similar between treated and control mice (data not shown) and characterized by intense destruction of ileal and colonic mucosa, fusion of colonic glandula, crypt abscesses, inflammatory infiltrate of stroma and congestion. 

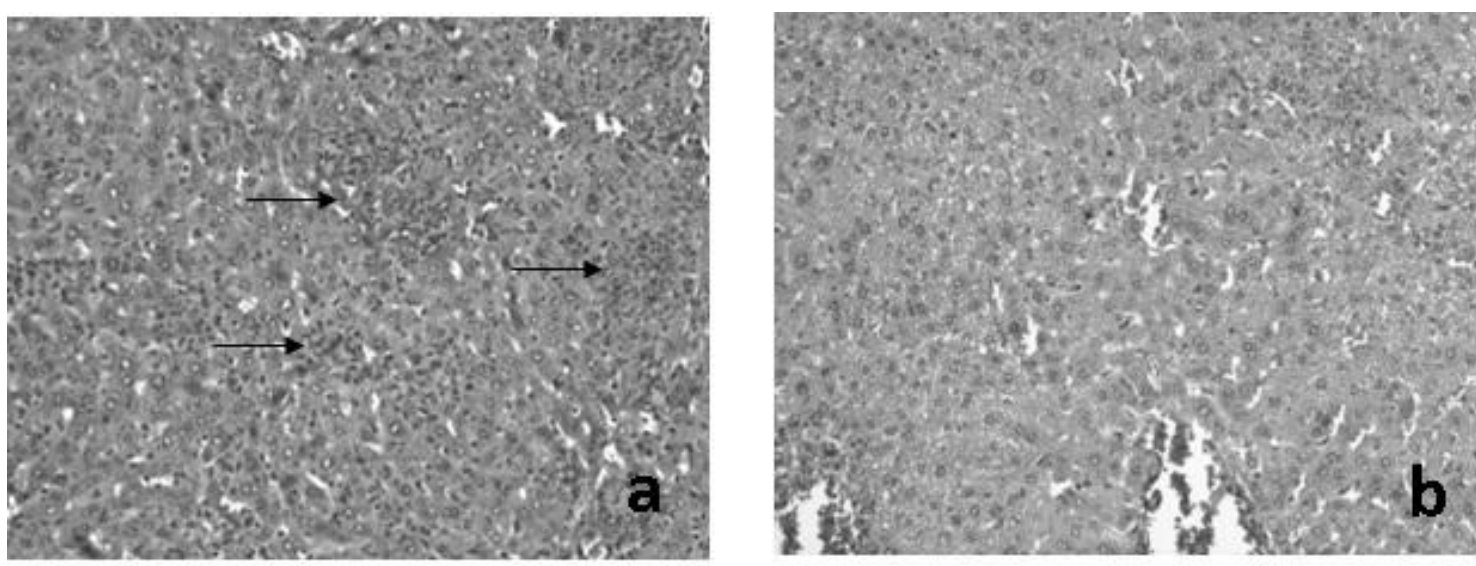

Figure 1. Histopathological aspect of the liver from gnotobiotic control (a) and treated (b) mice after challenge with Salmonella Typhimurium. Arrows show inflammatoty foci. Hematoxilin-eosin (350X).

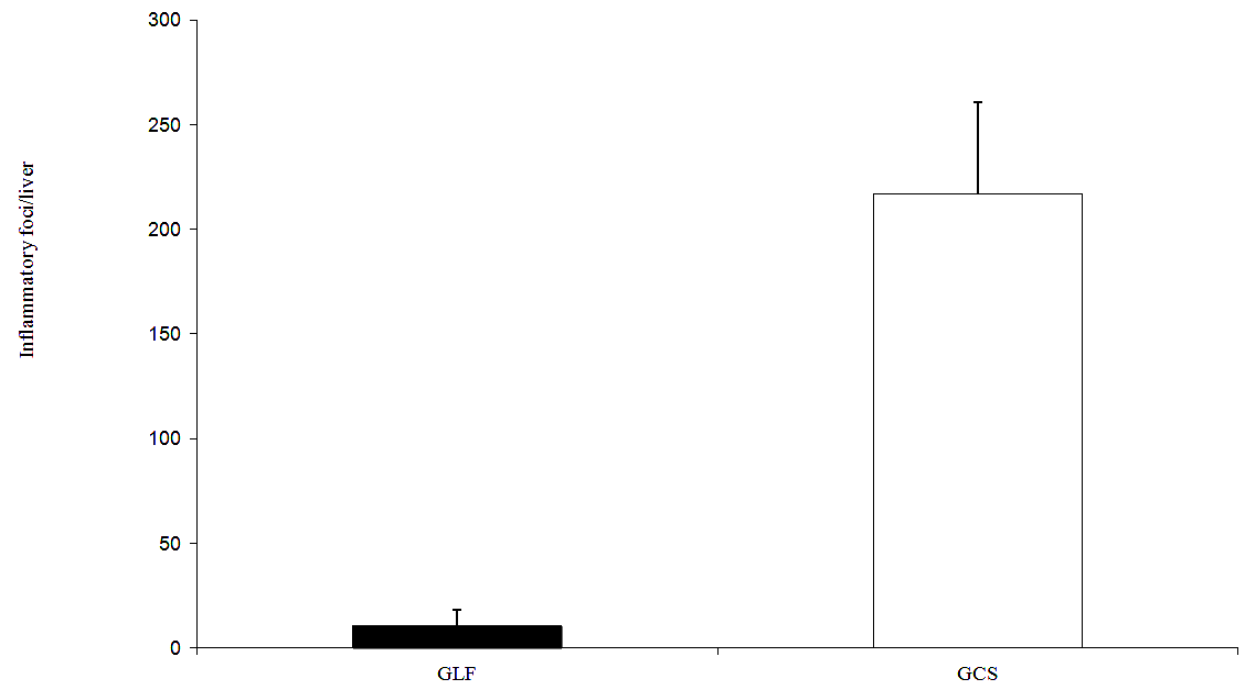

Figure 2. Number of inflammatory foci in the liver of gnotobiotic mice treated with Lactobacillus rhamnosus (GLF) or untreated gnotobiotic mice (GGS) after challenge with Salmonella Typhimurium $(* P<0.05)$.

L. rhamnosus became established in the digestive tract of gnotobiotic mice and the population level was about $9.0 \log \mathrm{CFU} / \mathrm{g}$ of feces (Fig. 3). After the challenge with the pathogen, the $L$. rhamnosus fecal population decreased to levels between 6.0 to $7.0 \log$ CFU/g of feces. Salmonella Typhimurium became similarly

established in the digestive tract of both treated and control mice with numbers ranging from 7.0 to $9.0 \log \mathrm{CFU} / \mathrm{g}$ of feces and remained at these high numbers until the animals died or were sacrificed in treated and control gnotobiotic mice (Fig. 3). 


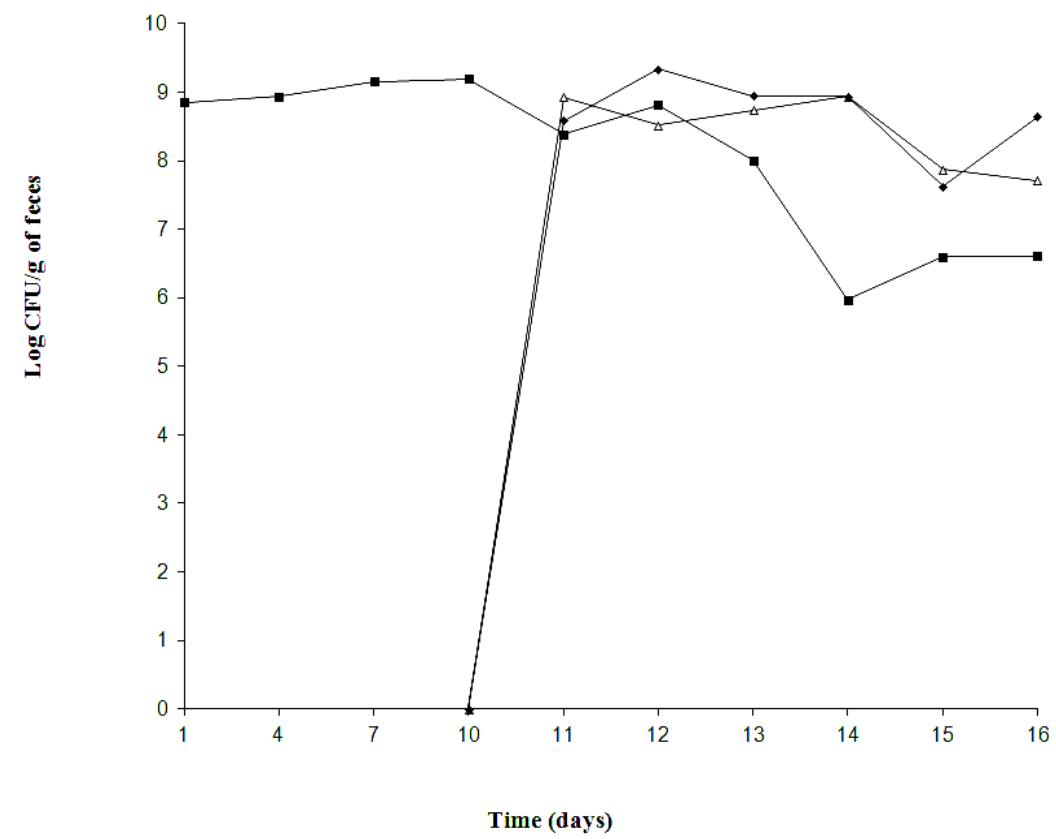

Figure 3. Fecal levels (log CFU/mL) of Lactobacillus rhamnosus $(\boldsymbol{\square})$ and Salmonella Typhimurium $(\Delta)$ in gnotobiotic mice treated with fermented milk, and fecal levels of $S$. Typhimurium $(\checkmark)$ in the untreated gnotobiotic mice.

In conventional animals, hepatic lesions were similar between treated and control mice and there was no significant difference $(P>0.05)$ for number of inflammatory foci between the two groups (Fig. 4). On the other hand, more severe lesions were observed in the intestines of conventional control animals when compared to the treated ones (Fig. 5). However, accumulated mortality was similar for the two groups (data not shown), both under gnotobiotic and conventional conditions.

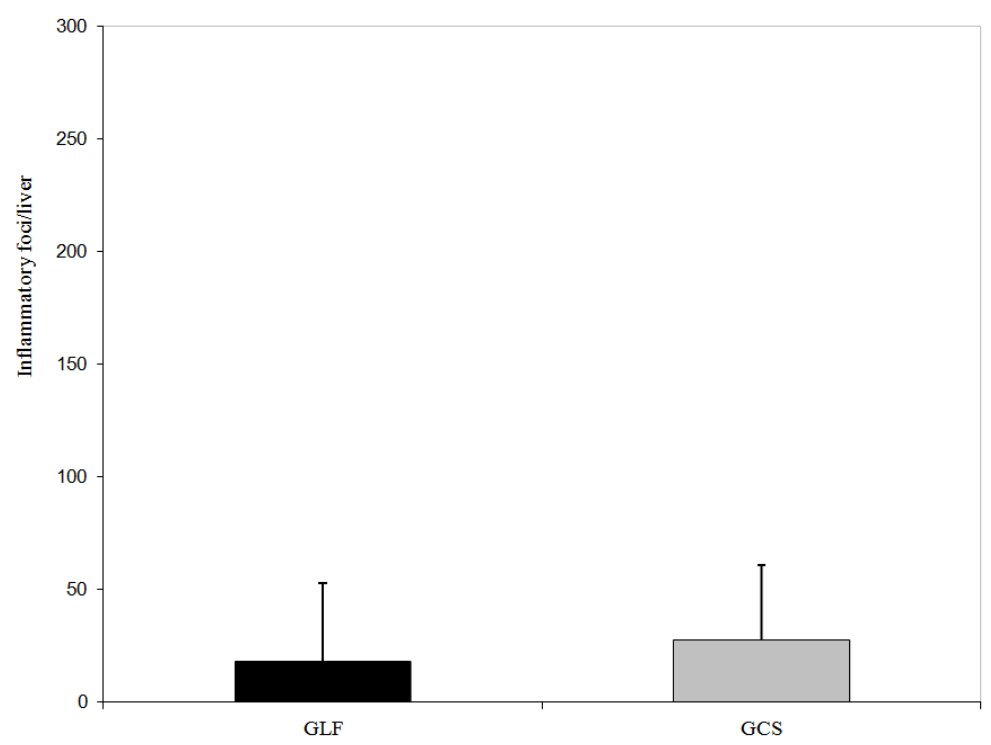

Figure 4. Number of inflammatory foci in the liver of conventional mice treated with Lactobacillus rhamnosus (GLF) or untreated conventional mice (GCS) after the challenge with Salmonella Typhimurium. 

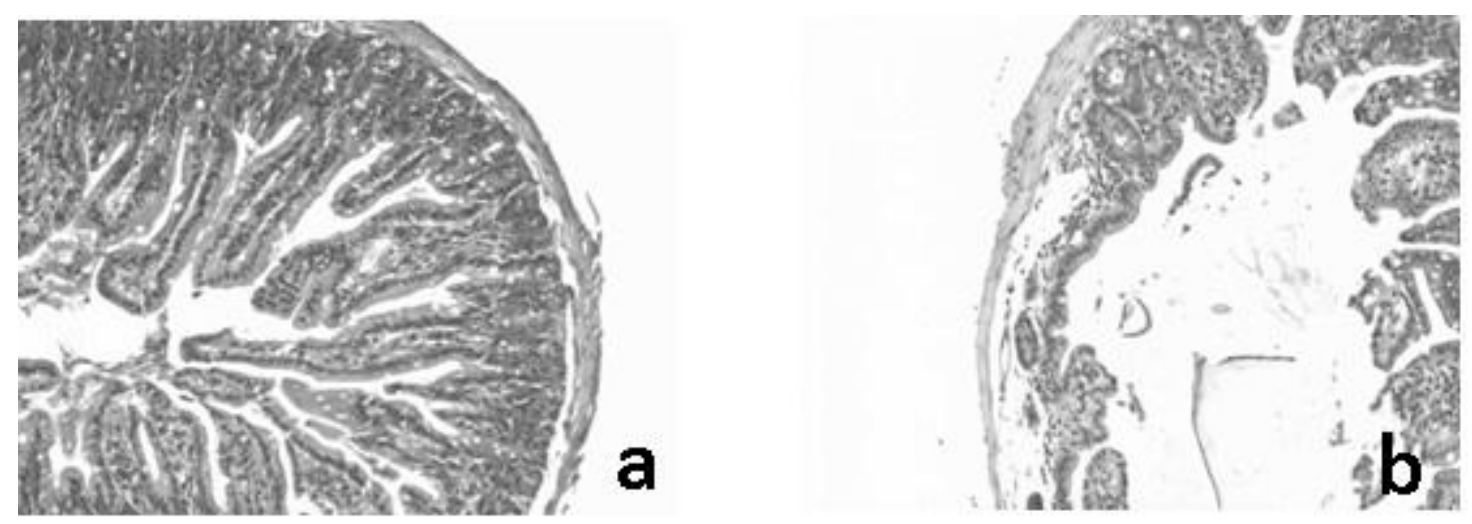

Figure 5. Histopathological aspect of ileum from treated (a) and untreated control (b) conventional mice after the challenge with Salmonella Typhimurium. Hematoxylin-eosin (140X).

\section{DISCUSSION}

Lactobacilli have the longest history of use as probiotics and are still the most common ingredients for preparations intended for consumption by human beings and animals. Like other probiotics, L. rhamnosus was drastically eliminated from the digestive tract of mammals harbouring a complex intestinal microbiota and for this reason the daily ingestion of these microorganisms was necessary to maintain high artificial levels in the gastrointestinal ecosystem of conventional animals. Thus, it is interesting to think of probiotics as altering community susceptibility to invasion without necessarily becoming permanent residents of the community (Silva et al., 1999; Robinson et al., 2010). On the other hand, its implantation was possible in germ-free animals using a single dose. Gnotobiotic mice were then used in the present study to obtain a simplified in vivo ecosystem allowing the observation of ecological interactions between the probiotic and the bacterial pathogen. The results were compared with those obtained using a similar experimental design, but with animals harboring a indigenous gastrointestinal microbiota (conventional) (Silva et al., 1999).

As expected and observed with other probiotics, the protection offered by L. rhamnosus against the pathogenic challenge was different between conventional and gnotobiotic animals due to the complementary protective effect from the indigenous intestinal microbiota and the biotherapeutic agent in the first case. Germ-free animals are extremely susceptible to experimental infection due to both the lack of ecological competition in the gastrointestinal lumen and to the underdeveloped immune system in the internal compartment (Rodrigues et al., 1996; Silva et al., 1999; Tham et al., 2011). This fact can explain, at least in part, the differences observed in the intestine protection in conventional and gnobiotic mice.

Additionally, the similar severity of intestinal lesions in treated and control gnotobiotic animals can be explained, at least in part, by the dyscrepancy of the primary sites of $S$. Typhimurium invasion and the antagonism effect of the lactobacilli used here. It is described that in vivo the terminal ileum is the primary site of $S$. Typhimurium invasion (Hudalt et al., 1997; Filho-Lima et al., 2000). However, Peyer's patches and $\mathrm{M}$ cells of the small intestine are the first to be involved (Hudalt et al., 1997). With this in mind, it should be noted that the microbial interactions differ in distinct sites. For instance, some lactobacilli strains can reduce drastically the E. coli population in the stomach of gnotobiotic mice, although the effect on the large intestine was significantly lower (Freter, 1992). Conversely, our previous ex-vivo experiments in gnotobiotic mice demonstrated that the diameter of the inhibition zone produced by L. rhamnosus against $S$. Typhimurium was not different in the distinc sites of the digestive tract (duodenum, jenunum, ileum, cecum, colon and feces).

A protective effect of L. rhamnosus against experimental $S$. Typhimurium was observed here and this protection was not due to the reduction of the population of pathogens in the intestine as demonstrated here by the similar population levels of the Salmonella in the feces from treated 
and control gnotobiotic mice (Fig. 3). However, in our previous in vitro and ex vivo experiments, the L. rhamnosus strain used here showed antagonistic properties against $S$. Typhimurium. A reduction in the population of the probiotic microorganism decreased after inoculation of Salmonella Typhimurium, as observed here, with L. rhamnosus strains as described by Salva et al. (2010).

Here we observed a lower number of inflammatory foci in the liver of treated gnotobiotic mice when compared to control gnotobiotic animals, although the hepatic lessions were similar in conventional animals (Fig. 4). This protection observed in treated gnotobiotic mice can be due to the reduced translocation of $S$. Typhumurium as proposed by other probiotics (Martins et al., 2007; Martins et al., 2010; Salva et al., 2010). This fact can be explained, at least in part, by the inhibition of both cell association and cell entry of this enterobacterium as described with other lactobacilli strains in enterocyte-like Caco-2 cells (Hudalt et al., 1997; Xu et al., 2009). With this in mind, Miyauchi et al. (2009) demonstrated that the L. rhamnosus OLL2838 is effective for the suppression of the tumor necrosis factor (TNF)- $\alpha$-induced barrier impairment in Caco-2 cells and dextran sodium sulfate-induced colitis in mice. In addition, Perdigon et al. (1988) demonstrated that the treatment of mice with $L$. casei suspension for three days stimulated the anti-Salmonella immunoglobulin-A antibodies and decreased the number of $S$. Typhimurium cells in the liver and spleen. Shu and Gill (2002) also observed that the previous supplementation with L. rhamnosus HN001 in mice challenged with Escherichia coli O157:H7 reduced the mortality rates and the pathogenic bacteria translocation rates and increased the anti-E. coli immunoglobulin-A titers and phagocytic rates, suggesting that the protection was due to cellular and humoral immunomodulation responses.

While the humoral response is important in protecting against intracellular pathogens, the cellular immunity is crucial (Bao et al., 2000; Salva et al., 2010). Interferon (IFN)- $\gamma$ produced by $\mathrm{T}$ cells and natural killer cells have shown to play an important role in the host defense against intracellular pathogens such as $S$. Typhimurium (Bao et al., 2000). Salva et al. (2010) described a significant increase in IFN- $\gamma$ in serum and intestinal fluid of mice fed with L. rhamnosus CRL1505 and L. rhamnosus CRL1506 strains. In vitro studies have shown that epithelial cells and fibroblasts are resistant to $S$. Typhimurium invasion in the presence of IFN- $\gamma$, which activated mouse epithelial macrophages, resulting in enhanced $S$. Typhimurium killing (Salva et al., 2010). Therefore, it is important to note that each Lactobacillus strain has specific properties and that its effect on the host's health cannot be extrapolated to other strains (FayolMessaoudi et al., 2005; Burkholder and Bhunia, 2009; Salva et al., 2010).

\section{CONCLUSIONS}

The L. rhamnosus strain used in the present study presented a potential probiotic use, however, futher studies are needed to determine the mechanisms by which this L. rhamnosus strain modulated the $S$. Typhimurium infection.

\section{ACKNOWLEDGMENTS}

This work was supported by grants from Conselho Nacional de Desenvolvimento Científico e Tecnológico (CNPq) and Fundação de Amparo à Pesquisa do Estado de Minas Gerais (FAPEMIG). We thank Maria Gorete Barbosa Ribas and Antônio Mesquita Vaz for valuable technical assistance.

\section{REFERENCES}

BAO, S.; BEAGLEY, K.W.; FRANCE, M.P. et al. Interferon-gamma plays a critical role in intestinal immunity against Salmonella typhimurium infection. Immunology, v.99, p.464-472, 2010.

BURKHOLDER, K.M.; BHUNIA, A.K. Salmonella enterica serovar Typhimurium adhesion and cytotoxicity during epithelial cell stress is reduced by Lactobacillus rhamnosus GG. Gut Pathog., v.1, p.14, 2009.

FAO/WHO. Guidelines for the evaluation of probiotics in food. Canada: London Ontario, 2002.

FAYOL-MESSAOUDI, D.; BERGER, C.N.; COCONNIER POLTER, M.H. et al. pH-, Lactic Acid-, and Non-lactic Acid-Dependent Activities of Probiotic Lactobacilli against Salmonella enterica serovar Typhimurium. Appl. Environ. Microbiol., v.71, p.6008-6013, 2005. 
FILHO-LIMA, J.V.M.; VIEIRA, E.C.; NICOLI, J.R. Antagonistic effect of Lactobacillus acidophilus, Saccharomyces boulardii and Escherichia coli combinations against experimental infections with Shigella flexneri and Salmonella enteritidis subsp. Typhimurium in gnotobiotic mice. J. Appl. Microbiol., v.88, p.365-370, 2000

FORESTEIR, C.; DE CHAMPS, C.; VATOUX, C.; JOLY, B. Probiotic activities of Lactobacillus casei rhamnosus: in vitro adherence to intestinal cells and antimicrobial properties. Res. Microbiol., v.152, p.167-173, 2001.

FRETER, R. Factors affecting the microecology of the gut. In: FULLER, R. (Ed). Probiotics: the scientific basis. London: Chapman \& Hall, 1992. p.111-143.

HUDALT, S.; LIÉVIN, V.; BERNET-CAMARAD, M.F.; SERVIN, A. Antagonistic activity exerted in vitro and in vivo by Lactobacillus casei (strain GG) against Salmonella Typhimurium C5 infection. Appl. Environ. Microbiol., v.63, p.513-518, 1997.

MARTINS, F.S.; DALMASSO, G.; ARANTES, R.M.E. et al. Interaction of Saccharomyces boulardi with Salmonella enterica serovar Typhimurium protects mice and modifies T84 cell response to the infection. PloS One, v.5:e8925, 2010.

MARTINS, F.S.; RODRIGUES, A.C.P.; TIAGO, F.C.P. et al. Saccharomyces cerevisiae strain 905 reduces the translocation of Salmonella enterica serotype Typhimurium and stimulates the immune system in gnotobiotic and conventional mice. J. Med. Microbiol., v.56, p.352-359, 2007.

MIYAUCHI, E.; MORITA, H.; TANABE, S. Lactobacillus rhamnosus alleviates intestinal barrier dysfunction in part by increasing expression of zonula occludens-1 and myosin light-chain kinase in vivo. $J$. Dairy Sci., v.92, p.2400-2408, 2009.

NATIONAL Research Council. Guide for the Care and Use of Laboratory Animals. Washington: National Academy Press, 1996. 246p.
PERDIGON, G.; ALVAREZ, S.; MEDICI, M. Systemic and local augmentation of the immune response in mice by feeding with milk fermented with Lactobacillus acidophilus and/or Lactobacillus casei. Immunology, v.63, p.17-23, 1988.

PLEASANTS, J.R Gnotobiotics. In: MELBY JR., E.C.; ALTMANN, E.C. (Ed.) Handbook of Laboratory Animal Science. Clevand: CRC Press, 1974. p.119-174.

ROBINSON, C.J.; BOHANNAN, B.J.M.; YOUNG, V.B. From structure to function: the ecology of hostassociated microbial communities. Microbiol. Mol. Biol. R., v.74, p.453-476, 2010.

RODRIGUES, A.C.P.; NARDI, R.M.; BAMBIRRA, E.A. et al. Effect of Saccharomyces boulardii against experimental oral infection with Salmonella typhimurium and Shigella flexneri in conventional and gnotobiotic mice. J. Appl. Bacteriol., v.81, p.251-256, 1996.

SALVA, S.; VILLENA, J.; ALVAREZ, S. Immunomodulatory activity of Lactobacillus rhamnosus isolated from goat milk: Impact on intestinal and respiratory infections. Int. J. Food Microbiol., v.141, p.82-89, 2010.

SILVA, A.M.; BAMBIRRA, E.A.; OLIVEIRA, A.L. et al. Protective effect of bifidus milk on the experimental infection with Salmonella enteritidis subsp. Typhimurium in conventional and gnotobiotic mice. J. Appl. Microbiol., v.86, p.331-336, 1999.

SHU, Q.; GILL, H.S. Immune protection mediated by the probiotic Lactobacillus rhamnosus HN001 (DR20TM) against Escherichia coli O157:H7 infection in mice. FEMS Immunol. Med. Microb., v.34, p.59-64, 2002.

THAM, C.S-C.; PEH, K-K.; BHAT, R.; LIONG, M-T. Probiotic properties of bifidobacteria and lactobacilli isolated from local dairy products. Ann. Microbiol., v.62, p.1079, 2011.

XU, H.; JEONG, H.S.; LEE, H.Y.; AHN, J. Assessment of cell surface properties and adhesion potential of selected probiotic strains. Lett. Appl. Microbiol., v.49, p.434-442, 2009. 